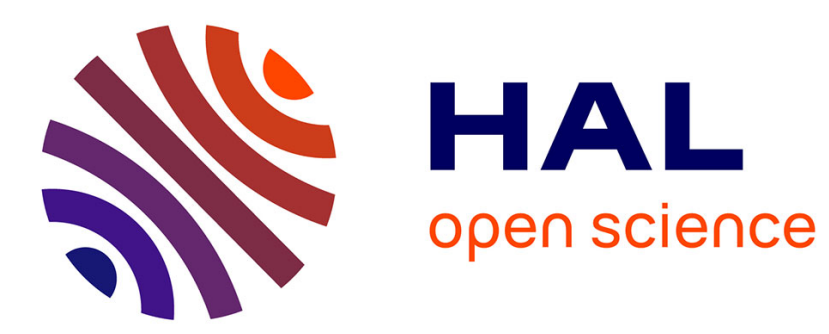

\title{
Production of glued laminated timber with copper azole treated maritime pine
}

Florindo Gaspar, Helena Cruz, Augusto Gomes, Lina Nunes

\section{To cite this version:}

Florindo Gaspar, Helena Cruz, Augusto Gomes, Lina Nunes. Production of glued laminated timber with copper azole treated maritime pine. European Journal of Wood and Wood Products, 2009, 68 (2), pp.207-218. 10.1007/s00107-009-0373-6 . hal-00568251

\section{HAL Id: hal-00568251 https://hal.science/hal-00568251}

Submitted on 23 Feb 2011

HAL is a multi-disciplinary open access archive for the deposit and dissemination of scientific research documents, whether they are published or not. The documents may come from teaching and research institutions in France or abroad, or from public or private research centers.
L'archive ouverte pluridisciplinaire HAL, est destinée au dépôt et à la diffusion de documents scientifiques de niveau recherche, publiés ou non, émanant des établissements d'enseignement et de recherche français ou étrangers, des laboratoires publics ou privés. 


\section{焦 Springer}

Draft Manuscript for Review

\section{Production of Glued Laminated Timber with Copper Azole Treated Maritime Pine}

\begin{tabular}{|r|l|}
\hline Journal: & Holz als Roh- und Werkstoff \\
\hline Manuscript ID: & HRW-09-0015.R1 \\
\hline Manuscript Type: & ORIGINALARBEITEN / ORIGINALS \\
\hline Author: & 09-Jun-2009 \\
\hline & $\begin{array}{l}\text { Complete List of Authors: } \\
\text { Gepartment } \\
\text { Gemes, Augusto; Technical University of Lisbon, Instituto Superior } \\
\text { Técnico, Department of Civil Engineering } \\
\text { Nunes, Lina; Laboratório Nacional de Engenharia Civil, Structures } \\
\text { Department }\end{array}$ \\
\hline Keywords: & $\begin{array}{l}\text { Glued laminated timber, Copper azole preservatives, Maritime pine, } \\
\text { Delamination }\end{array}$ \\
\hline & \\
\hline
\end{tabular}

\section{ScholarONE \\ Manuscript Central}




\begin{abstract}
A study was conducted to evaluate the performance of glued laminated timber (glulam) of maritime pine treated with a copper azole preservative product. Shear strength of glue lines met the requirements of EN 386 (2001) with no influence of clamping pressure and cure temperature. According to the same standard, delamination was satisfactory for higher cure temperatures applied with a clamping pressure of $0.6 \mathrm{~N} / \mathrm{mm}^{2}$. Finger joints made with treated wood gave satisfactory bending strength. The preservative treatment did not influence the modulus of elasticity of the beams. According to a Monte Carlo simulation and following the requirements of EN 1194 (2002), glulam of class GL 28c can be manufactured if visually graded maritime pine of classes E and EE (NP 4305 1995) is used in the inner and outer lamellas, respectively, and class GL $24 \mathrm{~h}$ when using both grades in equal proportions randomly distributed through the glulam element.
\end{abstract}

\title{
Herstellung von Brettschichtholz aus mit Kupferazol behandelter Strandkiefer
}

\section{Zusammenfassung}

In dieser Studie wurden die Eigenschaften von Brettschichtholz (Glulam) aus Strandkiefernholz, das mit Kupferazol-Schutzmittel behandelt wurde, untersucht. Die Scherfestigkeit der Klebstofffugen erfüllte die Anforderungen der EN 386 (2001). Dabei hatten der Pressdruck und die Aushärtungstemperatur keinen Einfluss. Bei höheren Aushärtungstemperaturen und einem Spanndruck von $0,6 \mathrm{~N} / \mathrm{mm}^{2}$ ergaben sich bezüglich den Anforderungen der EN 386 zufrieden stellende Delaminierungsergebnisse. Die Biegefestigkeit der Keilzinkenverbindungen aus behandeltem Holz war ebenfalls zufrieden stellend. Die Schutzmittelbehandlung hatte keinen Einfluss auf den E-Modul der Träger. Eine Monte-Carlo-Simulation ergab, dass auf Basis der EN 1194 (2002) Brettschichtholz der Klasse GL 28c hergestellt werden kann, wenn für die inneren bzw. äußeren Lamellen visuell sortiertes Strandkiefernholz der Klassen E bzw. EE (NP 4305:1995) verwendet wird, oder dass Klasse GL24h hergestellt werden kann, wenn beide Klassen zu gleichen Anteilen zufällig im Querschnitt verteilt verwendet werden. 


\section{INTRODUCTION}

The characteristically large size of knots of maritime pine (Pinus pinaster Ait) has been a justification for its usage for non structural purposes like pulpwood, panels and flooring. However, its physical properties are similar to the ones of other species currently used to produce glued laminated timber, and its clear wood has excellent mechanical properties that can be used for structural purposes (Pommier et al. 2005). Maritime pine has proven to be a good choice for glued laminated timber (Costa 1978; Cruz 1985; Sousa 1990) both for mechanical and economical reasons (Sousa 1990) and this suitability is recognized by the inclusion of maritime pine in the European Standard EN 386 (2001).

Nevertheless, the use of untreated wood on glued laminated elements is somewhat restrictive. The glue lines are not a barrier to the proliferation of insects and fungus (Nunes and Cruz 1991; Serment 1977) and the large cross-sections used in glued laminated members do not always guarantee sufficient inertia to temporary wet environments or accidental water intake, especially in use classes 3 and 4 (EN 335-2 2006). To reach adequate protection against biological attack, glued laminated timber should be produced from suitably durable species or it should be treated with a preservative. Some species, namely the mostly used spruce (Picea abies $\mathrm{H}$. Karsten) are difficult to treat restricting its uses. Maritime pine with its easy to impregnate sapwood can be a good alternative when deep preservative treatment is needed.

Preservative treatment can be done prior to or after gluing. However, treatment after gluing is generally limited to surface protection, since not only changes in moisture content (due to deep impregnation with commonly used water-borne products) after gluing are highly undesirable, but also the deep-treatment of full size glulam members raises some technical and practical problems (Selbo 1957). Deep-treatment of timber with water-borne preservatives prior to gluing has the advantage of increased compatibility with adhesives and lower costs, when compared with oil-borne preservatives. Furthermore, the size of the glulam members is not limited by the size of treatment cylinders and they can be securely bored and finished without exposing untreated wood.

On the other hand, the performance against delamination of the glued lines of laminated timber made of preservative treated wood is recognised to be lower than the untreated elements. Although CCA (chromated copper arsenate) preservatives were extensively used, environmental and health concerns on the release of arsenic from the wood led to the development of alternative copper compounds like alkaline copper quaternary (ACQ) and copper azoles (CA).

Performance of glued treated wood

According to Lorenz and Frihart (2006) there are several reasons which can explain the differences in performance of glued treated wood like chemical interference of the preservative with the adhesive cure, reduction of the wood wettability and physical blockage of the surface where the adhesive attaches to the wood. 
Miyazaki et al (1999) for instance, studied the adhesive properties of larch species (Larix sp.) bonded with a phenol-resorcinol-formaldeyde (PRF) adhesive after impregnation with AAC (alkyl ammonium compounds), ACQ and CA preservatives. Effects of treatment on the bondability under wet and dry conditions were discussed on the basis of the surface wettability and both the viscoelasticity and the infrared spectra of the resin with the addition of preservatives. They concluded that wettability was not changed by the preservative treatments and that the addition of these preservatives accelerated the cure of PRF.

On the other hand, using scanning electron microscopy, Vick and Kuster (1992) showed that cell lumen surfaces of CCA-treated southern pine were thoroughly covered with deposits consisting of mixtures of chromium, copper and arsenic. These deposits block most opportunities for bonding by molecular-level forces of attraction between polar wood constituents and adhesive. They also concluded that mechanical interlocking by a deeply penetrating phenolic adhesive can produce delamination-free bonds to CCA-treated southern pine.

When a commercial PRF formulation adhesive was used to glue treated southern yellow pine, Frihart (2003) found that resistance to delamination, according to ASTM D 2559 (American Society for Testing Materials 2000), decreased in the order of $\mathrm{CCA}>\mathrm{CA}>\mathrm{ACQ}$. A similar order was observed in the acceleration of cure as measured by the peak exothermic temperature using differential scanning calorimetry. In fact, Lorenz and Frihart (2006), confirming the results of Vick and Christiansen (1993), found that CCA-treated dust did not accelerate the cure of PRF adhesive when using differential scanning calorimetry. On the other hand, CA and ACQ preservatives did significantly decrease the cure temperature due to the presence of copper, reducing the penetration of the adhesive into the wood.

\section{Improvement of bonding quality}

Despite the reported problems of gluing treated timber, some studies report on successful experiments using similar procedures to that of gluing untreated woods. Podgorski and Legrand (2006) used Scots pine (Pinus silvestris L.) species treated with one CCA type preservative and three chromium and arsenic free formulations. Gluing was done with PRF, melamine-urea-formaldehyde (MUF) and polyurethane (PU) adhesives at $20^{\circ} \mathrm{C}$ and $65 \%$ relative humidity with a clamping pressure of $0.7 \mathrm{~N} / \mathrm{mm}^{2} \mathrm{kept}$ for $16 \mathrm{~h}$. Shear tests (EN 392 1995) and delamination tests (EN 3912001 ) showed satisfactory gluability according to the requirements of EN 386 (2001).

Lee et al. (2006) assessed the shear strength of Korean pine (Pinus koraiensis Sieb. et Zucc.) and Japanese larch (Larix leptolepis [Sieb. et Zucc.] Gordon) treated with CCA, copper-azole and CB-HDO (a preservative containing Bis-(Ncyclohexyldiazeniumdioxy)-copper ( $\mathrm{Cu}-\mathrm{HDO})$, copper hydroxide carbonate and boric acid), glued with MUF, melamine-formaldehyde (MF), phenolformaldehyde (PF) and resorcinol-formaldehyde (RF) adhesives. Gluing was done at room temperature for $24 \mathrm{~h}$ applying a clamping pressure of $0.79 \mathrm{~N} / \mathrm{mm}^{2}$. Although gluing quality was not evaluated by delamination test, satisfactory shear strength was obtained according to ASTM D 905 (American Society for Testing Materials 1994). This study also demonstrated the importance of the proper combination of preservative, wood species and adhesive to obtain better bonding 
strength. Good shear strength was achieved using PF and RF adhesives with pine wood treated with CB-HDO or copper azole products.

Miyazaki and Nakano (2003) also reported satisfactory shear and delamination strengths evaluated on the basis of the Japanese Agricultural Standard when studying the effects of three commercial preservatives such as AAC, ACQ, and $\mathrm{CA}$ on commercial adhesive properties such as PRF, RF and aqueous vinyl polymer solution-isocyanate.

Various authors tried to improve the bonding quality of treated wood through modification of the materials used, namely by reformulating adhesives or using a hydroxymethylated resorcinol (HMR) primer, or by changing the gluing procedure, namely by increasing the pressing time and cure temperature.

Successful gluing of treated wood was first achieved Truax et al. (1953), Selbo (1957, 1959) and Raknes (1963) by applying longer pressing and higher cure temperatures, namely by

Truax et al. (1953) reported results obtained on southern yellow pine and Douglas fir treated with two water-borne preservative products and glued at $49^{\circ} \mathrm{C}$ for $8 \mathrm{~h}$, as well as on red oak treated with five water-borne preservatives, pentachlorophenol and copper naphthenate, glued at $66^{\circ} \mathrm{C}$ for $9 \mathrm{~h}$. These times and temperatures were the minimum considered safe for development of adequate glue joints. Adhesives used were RF and PRF. Shear strength was in some cases slightly lower for treated samples although with high wood failure. Delamination was greater for treated samples but the results still fell within acceptable limits.

Selbo (1957) complemented the research reported by Truax et al (1953) using the same wood species, adhesives and preservative treatments, concluding that adequate glue bonds can be achieved with one of the water-borne preservative products used on red oak with curing as low as $54^{\circ} \mathrm{C}$ and on southern yellow pine with curing at $27^{\circ} \mathrm{C}$.

Raknes (1963) carried out experimental work using beech wood treated with water-borne preservatives (CC and CCA types) with two levels of preservative retention, glued with $\mathrm{RF}, \mathrm{PRF}$ and $\mathrm{PF}$ adhesives cured at $20^{\circ} \mathrm{C}$ and $40^{\circ} \mathrm{C}$. Clamping pressures were $0.69 \mathrm{~N} / \mathrm{mm}^{2}$ and $2.07 \mathrm{~N} / \mathrm{mm}^{2}$ for $12 \mathrm{~h}$, thus also observing the effect of the clamping pressure. Glue lines were tested in tension. Conclusions emphasize the beneficial effect of higher curing temperatures and the negative effect of too high clamping pressures. He reports that beech wood can be satisfactorily bonded with RF and PRF adhesives even at fairly high retentions of preservative.

Selbo (1959) summarized the information on gluing treated wood, analysing the results of various studies involving block shear tests and delamination. Recommendations were done for gluing various treated wood species, adhesives and preservatives applied by pressure impregnation. For the water-borne preservatives used, RF and PRF adhesives were found to be suitable. When dense hardwoods are glued, curing at a glue line temperature of $66^{\circ} \mathrm{C}$ to $77^{\circ} \mathrm{C}$ is suggested. For softwoods, curing temperatures of $49^{\circ} \mathrm{C}$ to $66^{\circ} \mathrm{C}$ may be satisfactory, although with certain adhesives $27^{\circ} \mathrm{C}$ may be adequate. 
Reformulation of the adhesive for gluing treated wood was done, namely by Sellers and Miller (1997) and Lisperguer and Becker (2005). Sellers and Miller (1997) used southern pine preservative treated with a CCA type product, glued with a clamping pressure of $0.93 \mathrm{~N} / \mathrm{mm}^{2}$ for $24 \mathrm{~h}$ in a cold press. Adhesives used were a commercial RF adhesive and a laboratory modified resorcinol adhesive mixture containing small amounts of additives (polymeric methylene diphenylmethane disocyanate, bark tannin, zinc acetate and ethanol) for possibly enhanced performance. Although satisfactory results were obtained for shear strength and delamination, according to the AITC Inspection Manual (American Institute of Timber Construction 1992) for both adhesives, the modified RF did not enhance the bond performance as expected.

Lisperguer and Becker (2005) studied the quality of the adhesive bonds for Pinus radiata $\mathrm{D}$. Don Chilean wood treated with CCA preservative. The performance of a commercial PRF resin was compared with another PRF resin synthesized in the laboratory, which had higher resorcinol content (25\%). For gluing, a clamping pressure of $0.6 \mathrm{~N} / \mathrm{mm}^{2}$ was applied for approximately $24 \mathrm{~h}$ at room temperature $\left(18^{\circ} \mathrm{C}\right)$. Satisfactory shear strength (ASTM D 905) was measured with both types of adhesives. However only the laboratory-synthesized adhesive successfully passed the three delamination cycles (ASTM D 2559).

Some studies were also carried out using a hydroxymethylated resorcinol (HMR) primer prior to the application of the adhesive. Vick (1995) used two commercially important PRF adhesives after the application of the HMR primer to glue CCA treated southern pine, using a clamping pressure of $0.69 \mathrm{~N} / \mathrm{mm}^{2}$ for $15 \mathrm{~h}$ at room temperature. Resistance to delamination met the 5 percent maximum delamination requirement of ASTM D 2559.

Vick (1997) also used the same primer type, wood species and preservative treatment, with commercial MUF and MF adhesives. Gluing was performed with radiofrequency curing, using a clamping pressure of $0.69 \mathrm{~N} / \mathrm{mm}^{2}$. Being however above the 5 percent maximum delamination (ASTM D 2559) requirement, the HMR primer greatly enhanced the durability of MUF and MF bonds to southern pine.

Lorenz and Frihart (2006) used southern yellow pine treated with CCA, ACQ and CA preservatives. Gluing was done with a HMR primer and a commercial PRF adhesive, using a clamping pressure of $1.03 \mathrm{~N} / \mathrm{mm}^{2}$ for $8 \mathrm{~h}$ in a cold press. Delamination was considerably reduced when using a HMR primer. However, better delamination results were obtained for untreated and CCA treated wood than for wood treated with ACQ and CA preservatives, being worst in the case of ACQ preservative that did not meet the 5\% delamination requirement of ASTM D 2559. Penetration of the HMR primer into the wood was in good agreement with the delamination results.

Treated maritime pine timber can be an alternative for glued laminated timber. However, its application needs further research, particularly in the scope of the recent restrictions to traditional preservative products (e.g., CCA). The development of this type of glued laminated timber can bring potential benefits, allowing its use in service conditions where elements are exposed to outside 
environment. This study was conducted with the objective of evaluating the gluability and the strength of glued laminated timber made of maritime pine deeptreated with a copper azole preservative product.

\section{EXPERIMENTAL WORK}

\subsection{Materials and methods}

The experimental work aimed at evaluating the effect of preservative retention, curing temperature and clamping pressure on the glue line performance.

Maritime pine timber planks treated with a copper azole preservative were used to produce glued laminated beams. Treatment was done using the empty cell process with two target retentions suitable for use classes 3 and 4 according to LNEC (National Civil Engineering Laboratory) homologation document DH 723 (2003). The control of the treatment retention level was done by atomic absorption spectroscopy following the standard A11 of AWPA (American Wood-Preservers' Association 1998). The determined average (of 3 specimens) retention were 7.6 $\mathrm{kg} / \mathrm{m}^{3}$ and $19.1 \mathrm{~kg} / \mathrm{m}^{3}$ for the lower and higher retention levels, respectively, hereafter called treatment levels $\mathrm{L}$ and $\mathrm{H}$. Following treatment, the planks were first air dried for product fixation and then kiln dried to about $14 \%$ moisture content. All planks were then conditioned at the reference conditions of $20^{\circ} \mathrm{C}$ and $65 \%$ relative humidity. The experimental work also included untreated timber of the same species, used as control, hereafter called treatment level $\mathrm{Z}$. The measured mean density of the untreated timber was $600 \mathrm{~kg} / \mathrm{m}^{3}$ whereas treated planks had $630 \mathrm{~kg} / \mathrm{m}^{3}$ (both retention levels).

The glued laminated timber beams were produced in two phases. In the first phase, the manufacture was done at a glulam factory with curing at room temperature $\left(18^{\circ} \mathrm{C}\right.$ on average) and applying three clamping pressures during $24 \mathrm{~h}$ whereas the second phase was conducted in laboratory environment at LNEC using one single clamping pressure and three higher curing temperatures $\left(20^{\circ} \mathrm{C}\right.$, $30^{\circ} \mathrm{C}$, and $45^{\circ} \mathrm{C}$ ) during $24 \mathrm{~h}$. In both phases the three wood treatment levels mentioned above were used, and the PRF adhesive currently used in the glulam factory manufacture was applied for face gluing according to the manufacturer instructions. Finger joint gluing was done using a MUF type adhesive.

When bonding at room temperature, beams and finger joint specimens were produced for testing. In face gluing, low pressures near $0.7 \mathrm{~N} / \mathrm{mm}^{2}$ are generally suitable for low density wood, whereas high pressures up to $1.7 \mathrm{~N} / \mathrm{mm}^{2}$ may be required for the highest density woods (Vick 1999). Additionally, Raknes (1963) found an undesirable effect when too high clamping pressures were used. Adhesive manufacturers usually give a range of recommended clamping pressures that shall also be followed.

Maritime pine timber, having a higher density than the majority of the species used on glued laminated timber, shall be used accordingly with a higher adequate clamping pressure. To find the adequate clamping pressure for face gluing, this variable was considered using three different values $\left(0.6 \mathrm{~N} / \mathrm{mm}^{2}, 0.9 \mathrm{~N} / \mathrm{mm}^{2}\right.$ and 
$1.12 \mathrm{~N} / \mathrm{mm}^{2}$ ). In total 27 beams with $2.90 \mathrm{~m}$ in length, $0.15 \mathrm{~m}$ in height and 0.08 $\mathrm{m}$ in width were obtained, each beam with five finger-jointed lamellas of $0.03 \mathrm{~m}$ thickness. These correspond to three replications for each combination of wood treatment level (Z, L, and H) and clamping pressures. Finger joints were presented in the middle third of the two outermost lamellas (tension side) of all beams, except for two beams of each treatment level $\mathrm{Z}$ and $\mathrm{L}$ and for one beam of level $\mathrm{H}$. Finger joint specimens were produced with the common production geometry of $0.02 \mathrm{~m}$ for the length, $0.0062 \mathrm{~m}$ for the pitch and $0.001 \mathrm{~m}$ for the tip width.

When bonding at higher cure temperatures, 12 beams of 4 lamellas were produced with $1 \mathrm{~m}$ in length, $0.12 \mathrm{~m}$ in height and $0.08 \mathrm{~m}$ in width, one for each wood treatment level and cure temperature combination. The clamping pressure used was $0.6 \mathrm{~N} / \mathrm{mm}^{2}$, which corresponds to the standard pressure used in the factory, as this was also identified suitable from the results of delamination tests, as described below.

Bonding at room temperature was performed to also evaluate the bending strength of the beams produced. Prior to the manufacturing process, 73 planks of each treatment level, with average dimensions equal to $1.85 \mathrm{~m}$ in length, $0.035 \mathrm{~m}$ in height and $0.10 \mathrm{~m}$ in width, were strength graded by measuring the modulus of elasticity of every cross section spaced of $0.15 \mathrm{~m}$ in a three point bending test with a span of $0.90 \mathrm{~m}$. The ends of the pieces that could not be "machine graded" were visually graded as required by EN 14081-1 (2005) and EN 385 (2001). This procedure allowed ranking the strength of the planks and positioning the higher strength pieces in the outer lamellas of the beams in order to manufacture a combined glulam type. The planks were also visually graded according to NP 4305 (1995) in one of the two grades defined in this standard - E and EE - that correspond approximately to the strength classes C18 and C35 (EN 338 2003), respectively. Pieces that did not meet the requirements of grade $\mathrm{E}$ were rejected.

\subsection{Tests and results}

The gluing performance was evaluated by measuring shear strength and delamination in both production phases. The bending strength of the beams and finger joints cured at room temperature was also evaluated.

\subsubsection{Shear tests}

Shear tests were performed on block shear specimens (EN 392 1995). The shear strength of the wood lamellas was also measured and compared with the shear strength of the glue lines.

\section{Cure at room temperature}

The shear strength of the glue line met the requirements of EN 386 (2001), both for shear strength and wood failure percentage (Figure 1). Additionally, the individual shear strength obtained was considerably high (more than $10 \mathrm{~N} / \mathrm{mm}^{2}$ in all cases). Table 1 shows the mean values and standard deviation for the glue line shear strength. Mean values of the glue line shear strength are similar between clamping pressures for each wood treatment level as was confirmed by the ANOVA test. However, according to the same analysis of variance, it is significant to affirm (at 5\% level) that the mean glue line shear strength was affected by the treatment retention levels. According to the multiple comparison 
tests HSD-Tukey these differences are significant between untreated and treated specimens but are not significant between treatment levels $\mathrm{L}$ and $\mathrm{H}$. The slight increase of the average shear strength of glue lines noted for the preservative treated wood can originate from the analogous increment on the shear strength of wood samples with treatment retention (Table 1). This will be the object of further investigation.

\section{Cure at higher temperature}

The cure temperature influence on the glue line shear strength is not clear (Figure 2). For untreated wood, the shear strength of the glue lines seems to follow the variation of the shear strength of the wood. However, for treated wood, other factors, namely the chemical composition and physical structure of the glue lines, play an important role on the shear strength of glue lines.

For this production phase, the same samples were used for the shear tests of glue lines and wood, allowing for comparison of both results. So, it can be observed that the glue line shear strength is always lower than the wood shear strength raising the possibility of a lower quality of the treated wood joints in relation to the untreated ones. In the first production phase, the shear strength is only indicative since different samples were used to measure glue line and wood shear strengths.

It can also be observed that the glue line shear strength obtained in the first production phase is higher than in the second production phase (for $20^{\circ} \mathrm{C}$ ). The main reason could be the different quantities of material used for both production phases. In the first production phase, 72 planks with $1.85 \mathrm{~m}$ length were used for each treatment level whereas in the second production phase only 12 planks of average length equal to $1 \mathrm{~m}$ were employed. This led to significant differences in the shear strength. For instance, the untreated wood shear strength measured in the first production phase ranges from 8.8 to $16.4 \mathrm{~N} / \mathrm{mm}^{2}$ whereas in the second production phase the values obtained (for $20^{\circ} \mathrm{C}$ ) are between 9.6 and $13.2 \mathrm{~N} / \mathrm{mm}^{2}$. The higher quantity of material used for curing at room temperature included superior material quality that led to higher glue line shear strength.

\subsubsection{Delamination tests}

The delamination tests of the glued lines were carried out according to EN 391 (2001) following both methods A and B. Figure 3 shows the individual and average delamination values for each clamping pressure and wood treatment level (first production phase). The global tendency observed indicates that the highest clamping pressure $\left(1.12 \mathrm{~N} / \mathrm{mm}^{2}\right)$ and preservative treatment retentions gave roughly higher values of delamination, confirming that the use of too high clamping pressures is not favourable and that the delamination increases with the preservative retention in the treated wood. Some samples did not meet the requirements of EN 386 (2001). In fact, except for the higher retention, the lower clamping pressure $\left(0.6 \mathrm{~N} / \mathrm{mm}^{2}\right)$ was the only one that always met the delamination requirements for both test methods $\mathrm{A}$ and $\mathrm{B}$.

The influence of the cure temperature on the delamination was studied in the second round of tests (Figure 4). The delamination values are all lower than the results obtained for curing at room temperature, thus meeting the requirements of 
EN 386 (2001). According to the analysis of variance (ANOVA) done, it is significant to affirm (at 5\%) that the average value of delamination (for methods $\mathrm{A}$ and $\mathrm{B}$ ) was affected by the treatment retention level and by the curing temperature. The average delamination on both methods $\mathrm{A}$ and $\mathrm{B}$ decreases for higher cure temperatures and, as happened for curing at room temperature, increases for higher treatment retention as shown in Table 2. This means that the use of higher curing temperatures is a possible way to achieve satisfactory gluing performance of treated wood. In addition, the always desirable design details for increasing the structure durability by reducing water contact and retention are in this case of utmost importance.

Significant differences can be found between the delamination results of both production phases, namely on wood treatment level $\mathrm{H}$ specimens where average delamination for $20^{\circ} \mathrm{C}$ is equal to $2.8 \%$ while for room temperature the related delamination result (clamping pressure equal to $0.6 \mathrm{~N} / \mathrm{mm}^{2}$ ) is $9.2 \%$. The same happens with wood treatment levels $\mathrm{Z}$ and $\mathrm{L}$ but with lower differences. The reason for this could not only be the difference between the average curing temperatures given that other differences between the two production phases can contribute to the differences found. For instance, the delamination specimens of each production phase had different dimensions, because of the different cross sections of the beams, which could also lead to significantly different stresses during swelling and shrinking of the wood influencing the delamination results. The gluing procedures of two production phases have also some differences since they correspond to different manufacturing environments. For instance, the application of the adhesive at the glulam factory was done by the usual process of extrusion whereas at the laboratory the adhesive was applied manually using a plastic spreader, with which better glue line quality should be obtained. In addition, the curing temperature during the laboratory procedure was kept constant inside the cure chamber, while at the factory the room temperature was changed beginning with $15^{\circ} \mathrm{C}$ and reaching $24^{\circ} \mathrm{C}$ during some curing time. Given that temperature affects delamination, the lower temperatures affected the glue line quality.

\subsubsection{Bending tests of finger joints}

The bending tests of the finger joints were made according to EN 408 (2003). Each specimen was tested in a four point bending test over a span of 18 times the thickness $(0.03 \mathrm{~m}$ in this case), with loads applied at the thirds of the span. The strength was measured after 7 days of curing at room temperature. The results of tests made on samples of treated wood $(\mathrm{H})$ and of untreated wood $(\mathrm{Z})$ are summarized in Table 3.

The average bending strength decreases with treatment level. However, the characteristic value of treated wood is still slightly above the minimum required by EN 1194 (2002). According to this standard, the characteristic value of finger joint bending strength should be at least, $37.4 \mathrm{~N} / \mathrm{mm}^{2}$ when the strength class of timber is C35, which corresponds to grade EE of maritime pine (NP 4305). This means that the preservative treatment should not be a problem for the strength of the finger joints. 


\subsubsection{Bending tests of glulam beams}

The bending tests of the beams (first production phase) were conducted according to EN 408 (2003) with a span of $2.7 \mathrm{~m}$ and loading at the thirds of the span measuring the bending strength and the global modulus of elasticity.

The clamping pressure did not have a clear influence on the results (Figure 5). Bending strength was mainly influenced by the failure origin. The higher values observed relate to failures caused by finger joints located outside the central third of the beams, unlike the other cases. Table 4 shows the results corresponding to failures initiated within the central third of the beams.

Bending strength is clearly affected by treatment level, although in a somewhat unexpected way. The strength variation (first increasing and then decreasing with increasing treatment level) is however consistent with the shear strength variation of wood with preservative treatment shown in Table 1.

The average global modulus of elasticity was found to be similar for the three treatment groups suggesting that the treatment did not affect this property. The same evidence was verified on the measured modulus of elasticity of the planks (Tables 5 and 6). For the bending strength, the number of beams is not statistically significant and does not allow assigning the beams into a strength class. However the average and standard deviation values of bending strength are acceptable and will be confronted with the following statistical analysis.

\subsubsection{Statistical analysis of the bending strength}

In order to evaluate the conformity of the glulam beams with standard EN 1194 (2002), a first Monte Carlo simulation was made to estimate the strength of the planks used in the outer lamellas of beams. This simulation was performed according to the scheme illustrated in Figure 6. The minimum modulus of elasticity of each plank applied in the four outer lamellas was used to estimate its average bending strength through the regression line obtained by Machado and Cruz (1992). Each value of bending strength was used with the coefficients of variation of visually graded maritime pine, which are, according to Machado et al. (1998), $40 \%$ and $22 \%$ for the visual grades E and EE, respectively, to generate a normal probability distribution obtained with 200 random probability values for each plank. The characteristic bending strengths for each wood treatment level were obtained applying the not parametric method to this distribution, as indicated by EN 384 (2004) and the characteristic tension strengths were taken equal to $60 \%$ of the bending strengths following the same standard. Table 5 summarizes the results.

The equations given in EN 1194 (2002) to predict the bending strength and modulus of elasticity of beams from the properties of the lamellas were then applied using the predicted characteristic value of tension strength and the measured average modulus of elasticity (Table 5), indicating that the beams can be allocated to the glulam strength class GL 28c. Despite the small number of test results, the bending strength and modulus of elasticity of the beams tested (Table 4) was consistent with such strength class. 


\section{CONCLUSION}

The use of most softwood species in use classes 3 or 4 (EN 335-2 2006), either in solid or glued laminated elements, requires deep preservative treatment of the wood. Treatment before gluing is the most effective way to do this, but some technical problems related to the gluing process must be solved.

Shear strength of the glue lines of preservative treated wood was slightly higher than for untreated wood that was influenced by the great shear strength of the wood. Shear strength of glue lines met the requirements of EN 386 (2001) with no influence of clamping pressure and curing temperature.

Delamination increased with the increase of preservative retention and also with clamping pressure, and decreased with increasing curing temperature. Higher curing temperatures applied with a clamping pressure of $0.6 \mathrm{~N} / \mathrm{mm}^{2}$ gave suitable glue lines, according to the requirements of EN 386 (2001), although clamping pressures of $1.12 \mathrm{~N} / \mathrm{mm}^{2}$ led to higher values of delamination, showing an unacceptable performance.

These results show that the increase of curing temperature is a possible way to obtain good glue line performance when copper azole treated maritime pine is used, demonstrating its suitability for the production of glued laminated timber. However, despite the acceptable performance of the glue lines in the quality control tests, the preservative product had a negative influence on the glue line behaviour, increasing the delamination which may indicate a lower performance in service. So, the preservative retention should be the minimum possibly stressing the importance of the design of timber structures in order to reduce soil contact and water exposure (traps). 
Finger joints made with treated wood gave satisfactory bending strength that was, however, lower than for untreated wood. Its strength is compatible with the use of visual graded maritime pine planks of Portuguese visual grade EE (NP 4305).

The tested beams showed satisfactory strength, with a predicted strength class GL 28c (EN 1194 2002) and with no influence of clamping pressure. The preservative treatment did not influence the modulus of elasticity of the beams. According to the performed Monte Carlo simulation, and following EN 1194 (2002), visually graded maritime pine can be used to manufacture glued laminated timber of class GL 28c if grades $\mathrm{E}$ and $\mathrm{EE}$ are used in the inner and outer lamellas, respectively, and class GL $24 \mathrm{~h}$ if grades $\mathrm{E}$ and EE are used in equal proportions randomly distributed through the glued laminated element.

\section{Acknowledgements}

The authors wish to thank Fundação para a Ciência e a Tecnologia (Portuguese Foundation for Science and Technology), for the $\mathrm{PhD}$ grant (number SFRH/BD/30310/2006) given to Florindo Gaspar, and to Arch Timber Protection Ltd for the support.

\section{REFERENCES}

American Institute of Timber Construction (1992) Inspection manual. AITC, Englewood, Co

American Society for Testing Materials (2000) Standard Specification for Adhesives for Structural Laminated Wood Products for Use Under Exterior (Wet Use) Exposure Conditions. In: Annual Book of ASTM Standards, D2559-00, ASTM, West Conshohocken, Pa

American Society for Testing Materials (1994) Standard method of test for shear of adhesives by compression loading. In: Annual Book of ASTM Standards, D 905-94, ASTM, West Conshohocken, $\mathrm{Pa}$

American Wood-Preservers' Association (1998) A11-93: Standard method for analysis of treated wood and treating solutions by atomic absorption spectroscopy. American Wood-Preservers' Association Book of Standards (AWPA), Granbury, Tex

Costa J (1978) Aplicação da madeira de pinho bravo em estruturas coladas. Viabilidade da colagem. Laboratório Nacional de Engenharia Civil, Lisbon

Cruz H (1985) Aplicação da madeira de pinho bravo em estruturas lameladas-coladas. Ensaios de colagem para uso em condições de exposição exterior. Laboratório Nacional de Engenharia Civil, Lisbon

DH 723 (2003) TANALITH E 3497: Características e condições de emprego. Laboratório Nacional de Engenharia Civil, Lisbon

EN 335-2 (2006) Durability of wood and wood-based products. Definition of use classes. Part 2: Application to solid wood. European Committee for Standardization, Brussels

EN 338 (2003) Structural timber. Strength classes. European Committee for Standardization, Brussels, Brussels

EN 384 (2004) Structural timber - Determination of caracteristic values of mechanical properties and density. European Committee for Standardization, Brussels

EN 385 (2001) Finger jointed structural timber - Performance requirements and minimum production requirements. European Committee for Standardization, Brussels 
EN 386 (2001) Glued laminated timber. Performance requirements and minimum production requirements. European Committee for Standardization, Brussels

EN 391 (2001) Glued laminated timber. Delamination test of glue lines. European Committee for Standardization, Brussels

EN 392 (1995) Glued laminated timber. Shear test of glue lines. European Committee for Standardization. Brussels

EN 408 (2003) Timber structures. Structural timber and glued laminated timber. Determination of some physical and mechanical properties. European Committee for Standardization, Brussels

EN 1194 (2002) Timber structures. Glued laminated timber. Strength classes and determination of characteristic values. European Committee for Standardization, Brussels

EN 14081-1 (2005) Timber structures. Strength graded structural timber with rectangular cross section. Part 1: General requirements. European Committee for Standardization, Brussels

Frihart CR (2003) Interaction of copper wood preservatives and adhesives. In: Anderson GL (ed) Proceedings of 26th Annual Meeting of The Adhesion Society, Inc., The Adhesion Society, Blacksburg, VA., pp 244-245

Lee D-H, Lee MJ, Son D-W, Park B-D (2006) Adhesive performance of woods treated with alternative preservatives. Wood Sci Technol 40: 228-236

Lisperguer JH, Becker PH (2005) Strength and durability of phenol-resorcinol-formaldehyde bonds to CCA-treated radiata pine wood, Forest Prod J 55(12):113-116

Lorenz L, Frihart C (2006) Adhesive bonding of wood treated with ACQ and copper azole preservatives, Forest Prod J 56(9):90-93

Machado JS, Cruz H (1992) Madeira de Pinheiro bravo. Determinação dos valores característicos da tensão resistente à flexão. Laboratório Nacional de Engenharia Civil, report 39/92 - NM, Lisbon

Machado JS, Sardinha R, Cruz H (1998) Evaluation of lengthwise variation of mechanical properties by ultrasounds. In: Natterer J, Sandoz J-L (eds) Proceedings of the 5th World Conference on Timber Engineering, Presses Polytechniques et Universitaires Romandes Lausanne, vol 2, pp 304- 311

Miyazaki J, Nakano T, Hirabayashi Y, Kishino M (1999) Effects of wood preservatives on adhesion properties of phenol-formaldehyde resin. Mokuzai Gakkaishi 45(1):34-41

Miyazaki J, Nakano T (2003) Effects of wood preservatives on adhesive properties. IV. Effects of preservation and incising on shear strength and delamination. Mokuzai Gakkaishi 49(3):212-218

NP ENV 1995-1-1 (1998) Eurocódigo 5: Projecto de estruturas de madeira. Parte 1.1: Regras gerais e regras para edifícios. Instituto Português da Qualidade, Lisbon

NP 4305 (1995) Madeira serrada de pinheiro bravo para estruturas. Classificação visual. Instituto Português da Qualidade, Lisbon

Nunes L, Cruz H (1991) A laboratory evaluation of the susceptibility to biological attack of glued laminated pine timber. The International Research Group on Wood Preservation, paper prepared for the 22nd annual meeting, document $n^{\circ}$ IRG/WP/2387, Stockholm

Podgorski L, Legrand G (2006) Paintability and gluability of wood treated with arsenic-free and chromium-free preservative treatments, The International Research Group on Wood Protection, paper prepared for the 37th Annual Meeting, document n ${ }^{\circ}$ IRG/WP 06-40342, Stockholm 
Pommier R, Elbez G, Vierge G (2005) Valorisation of maritime pine thanks to green gluing technology. Economic considerations. In: Källander B (ed) Green gluing of wood - process products - market, COST Action E34 Bonding of Wood in cooperation with SP Swedish National Testing and Research Institute, Available via University of Hamburg, http://www1.unihamburg.de/cost/e34/conferences/2005-Boras/Boras_Proceedings_2005.pdf5, pp 63-66 Accessed 30 Jun 2008

Serment MM (1977) Risk of extension of Hylotrupes bajulus attack in glued laminated timber, The International Research Group on Wood Preservation, paper prepared for the 9th annual meeting, document $n^{\circ}$ IRG/WP/278, Stockholm

Sousa PM (1990) Estruturas de Madeira Lamelada-Colada, Viabilidade da Utilização do pinho bravo. Laboratório Nacional de Engenharia Civil, Lisbon

Raknes E (1963) Gluing of wood pressure-treated with water borne preservatives and flame retardants. J of the Inst of Wood Sci 11:24-44

Sellers T, Miller GD (1997) Evaluations of three adhesive systems for CCA-treated lumber. Forest Prod J 47(10): 73-76

Selbo ML (1957) Laminating of preservative-treated wood. In: Proceedings of AWPA, AWPA, Granbury, Tx, 53:48-55

Selbo ML (1959) Summary of information on gluing of treated wood. Report number 1785 (information reviewed and reaffirmed 1965), Forest Products Laboratory, Madison, Wi

Truax TR, Blew JO, Selbo ML (1953) Production of preservative-treated Laminated timbers. In: Proceedings of AWPA, AWPA, Granbury, Tx, 49:113-123

Vick CB, Kuster TA (1992) Mechanical interlocking of adhesive bonds to CCA-treated southern pine. A scanning electron microscopic study. Wood and Fiber Sci 24(1):36-46

Vick CB, Christiansen AW (1993) Cure of phenol-formal-dehyde adhesive in the presence of CCA-treated wood by differential scanning calorimetry. Wood and Fiber Sci 25(1):77-86

Vick CB (1995) Coupling agent improves durability of PRF bonds to CCA-treated southern pine. Forest Prod J 45(3):78-84

Vick CB (1997) Enhanced adhesion of melamine-urea and melamine adhesives to cca-treated southern pine lumber. Forest Prod J 47(7/8):83-87

Vick CB (1999) Adhesive Bonding of Wood Materials. In: Wood Handbook - Wood as an Engineering Material. Forest Products Laboratory, Madison, chapter 9 
Figure legends:

Fig. 1 Glue line shear test results (individual values) - curing at room temperature

Fig. 2 Average shear strength of glue lines and wood - curing at higher temperatures

Fig. 3 Results of the delamination tests - curing at room temperature

Fig. 4 Results of delamination tests - curing at higher temperatures

Fig. 5 Bending strength of beams. Values are corrected by $k_{\text {size }}$ factor, according to EN 1194 (2002)

Fig. 6 Scheme of the Monte Carlo simulation used to estimate the strength of the lamellas

Abb. 1 Ergebnisse der Scherprüfung der Klebstofffugen (Einzelwerte) - Aushärtung bei Raumtemperatur

Abb. 2 Mittlere Scherfestigkeit der Klebstofffugen und des Holzes - Aushärtung bei höheren Temperaturen

Abb. 3 Ergebnisse der Delaminierungsprüfungen - Aushärtung bei Raumtemperatur Abb. 4 Ergebnisse der Delaminierungsprüfungen - Aushärtung bei höheren Temperaturen Abb. 5 Biegefestigkeit der Träger. Die Werte wurden gemäß EN 1194 mit dem Faktor $k_{\text {size }}$ korrigiert

Abb. 6 Schema der Monte-Carlo-Simulation zur Herleitung der Festigkeit der Lamellen. 
Tables:

Table 1 Wood and glue line shear strength results - curing at room temperature

\begin{tabular}{|c|c|c|c|c|c|c|c|}
\hline \multirow{2}{*}{$\begin{array}{c}\text { Wood } \\
\text { treatment } \\
\text { level }\end{array}$} & \multirow{2}{*}{$\begin{array}{l}\text { Clamping } \\
\text { pressure } \\
\left(\mathrm{N} / \mathrm{mm}^{2}\right)\end{array}$} & \multicolumn{3}{|c|}{ Glue line shear strength $\left(\mathrm{N} / \mathrm{mm}^{2}\right)$} & \multicolumn{3}{|c|}{ Wood shear strength $\left(\mathrm{N} / \mathrm{mm}^{2}\right)$} \\
\hline & & $\begin{array}{l}\text { Number of } \\
\text { specimens }\end{array}$ & Average & $\begin{array}{l}\text { Standard } \\
\text { deviation }\end{array}$ & $\begin{array}{l}\text { Number of } \\
\text { specimens }\end{array}$ & Average & $\begin{array}{l}\text { Standard } \\
\text { deviation }\end{array}$ \\
\hline \multirow{3}{*}{$\mathrm{Z}$} & 1.12 & 21 & 14.2 & 1.1 & \multirow{3}{*}{53} & \multirow{3}{*}{12.6} & \multirow{3}{*}{1.6} \\
\hline & 0.9 & 24 & 13.3 & 1.5 & & & \\
\hline & 0.6 & 23 & 13.6 & 0.9 & & & \\
\hline \multirow{3}{*}{$\mathrm{L}$} & 1.12 & 24 & 14.4 & 1.2 & \multirow{3}{*}{50} & \multirow{3}{*}{13.9} & \multirow{3}{*}{1.6} \\
\hline & 0.9 & 23 & 14.4 & 1.2 & & & \\
\hline & 0.6 & 19 & 14.1 & 1.5 & & & \\
\hline \multirow{3}{*}{$\mathrm{H}$} & 1.12 & 21 & 14.4 & 1.0 & \multirow{3}{*}{63} & \multirow{3}{*}{13.4} & \multirow{3}{*}{1.3} \\
\hline & 0.9 & 24 & 14.2 & 0.9 & & & \\
\hline & 0.6 & 24 & 14.1 & 0.9 & & & \\
\hline
\end{tabular}

Table 2 Results of the average delamination for each wood treatment level and curing temperature

\begin{tabular}{lcccccc}
\hline & \multicolumn{3}{c}{ Wood treatment level } & \multicolumn{3}{c}{ Curing temperature $\left({ }^{\circ} \mathrm{C}\right)$} \\
\cline { 2 - 7 } & $\mathrm{Z}$ & $\mathrm{L}$ & $\mathrm{H}$ & 20 & 30 & 45 \\
\hline Number of specimens & 14 & 15 & 13 & 15 & 16 & 14 \\
\hline Average delamination $(\%)$ & 0.66 & 0.91 & 2.38 & 1.68 & 1.42 & 0.57 \\
\hline
\end{tabular}

Table 3 Results of the bending strength of finger joints in N/mm²

\begin{tabular}{lcc}
\hline & \multicolumn{2}{c}{ Wood treatment level } \\
\cline { 2 - 3 } & $\mathrm{Z}$ & $\mathrm{H}$ \\
\hline Sample size & 15 & 30 \\
Average & 54.3 & 49.4 \\
Standard deviation & 8.4 & 8.0 \\
Characteristic value $^{\mathrm{a}}$ & - & 37.8 \\
\hline${ }^{\mathrm{a}}$ - Determined by log-Normal probability function \\
\hline
\end{tabular}

Table 4 Results from the bending tests of the beams in N/mm² 
Table 5 Mechanical properties of timber and glulam considering the planks used on the four outer lamellas (combined glulam)

\begin{tabular}{c} 
Wood treatment level \\
\cline { 2 - 4 }
\end{tabular}

Mechanical properties of the planks used on the four outer lamellas

\begin{tabular}{|c|c|c|c|}
\hline Number of planks & $58^{\mathrm{d}}$ & $61^{\mathrm{e}}$ & $59^{\mathrm{f}}$ \\
\hline Average $\left(\mathrm{N} / \mathrm{mm}^{2}\right)$ & 74.8 & 75.6 & 74.7 \\
\hline Coefficient of variation (\%) & 32.3 & 37.3 & 34.5 \\
\hline Characteristic value $\left(\mathrm{N} / \mathrm{mm}^{2}\right)^{\mathrm{a}}$ & 36.1 & 31.4 & 33.1 \\
\hline Predicted characteristic tension strength $\left(\mathrm{N} / \mathrm{mm}^{2}\right)^{b}$ & 21.7 & 18.8 & 19.9 \\
\hline Measured average modulus of elasticity $\left(\mathrm{N} / \mathrm{mm}^{2}\right)$ & 14100 & 13900 & 13900 \\
\hline
\end{tabular}

Predicted mechanical properties of the glued laminated timber ${ }^{\mathrm{c}}$

\begin{tabular}{lccc}
\hline Characteristic bending strength $\left(\mathrm{N} / \mathrm{mm}^{2}\right)$ & 32.0 & 28.6 & 29.9 \\
\hline Average modulus of elasticity $\left(\mathrm{N} / \mathrm{mm}^{2}\right)$ & 14800 & 14600 & 14600 \\
\hline Characteristic modulus of elasticity $\left(\mathrm{N} / \mathrm{mm}^{2}\right)$ & 12000 & 11900 & 11900 \\
\hline a - By the not parametric method & & & \\
b - Equal to $60 \%$ of bending strength & & & \\
c - According to EN $1194(2002)$ & & & \\
d -25 are of grade E and 33 of grade EE & & & \\
e -40 are of grade E and 21 of grade EE & & & \\
f -33 are of grade E and 26 of grade EE & & \\
\hline
\end{tabular}

Table 6 Mechanical properties of timber and glulam considering all the planks used (homogeneous glulam)

\begin{tabular}{|c|c|c|c|c|}
\hline & & \multicolumn{3}{|c|}{ Wood treatment level } \\
\hline & & $\mathrm{Z}$ & $\mathrm{L}$ & $\mathrm{H}$ \\
\hline \multicolumn{5}{|c|}{ Mechanical properties of all the planks used } \\
\hline Number of & & $73^{\mathrm{d}}$ & $73^{\mathrm{e}}$ & $73^{f}$ \\
\hline \multirow{3}{*}{$\begin{array}{c}\text { Predicted } \\
\text { bending } \\
\text { strength }\end{array}$} & Average $\left(\mathrm{N} / \mathrm{mm}^{2}\right)$ & 72.1 & 71.4 & 70.9 \\
\hline & Coefficient of variation $(\%)$ & 35.0 & 40.4 & 46.9 \\
\hline & Characteristic value $\left(\mathrm{N} / \mathrm{mm}^{2}\right)^{\mathrm{a}}$ & 29.6 & 27.1 & 31.5 \\
\hline \multicolumn{2}{|c|}{ Predicted characteristic tension strength $\left(\mathrm{N} / \mathrm{mm}^{2}\right)^{\mathrm{b}}$} & 17.8 & 16.3 & 18.9 \\
\hline
\end{tabular}




\begin{tabular}{llll}
\hline Measured average modulus of elasticity $\left(\mathrm{N} / \mathrm{mm}^{2}\right)$ & 13200 & 13100 & 13300
\end{tabular}

Predicted mechanical properties of the glued laminated timber ${ }^{\mathrm{c}}$

\begin{tabular}{lccc}
\hline Characteristic bending strength $\left(\mathrm{N} / \mathrm{mm}^{2}\right)$ & 27.5 & 25.7 & 28.7 \\
\hline Average modulus of elasticity $\left(\mathrm{N} / \mathrm{mm}^{2}\right)$ & 13900 & 13700 & 13900 \\
\hline Characteristic modulus of elasticity $\left(\mathrm{N} / \mathrm{mm}^{2}\right)$ & 11200 & 11100 & 11300 \\
\hline a - By the not parametric method & & & \\
b - Equal to $60 \%$ of bending strength & & & \\
c - According to EN $1194(2002)$ & & & \\
d -37 are of grade E and 36 of grade EE & & & \\
e -47 are of grade E and 26 of grade EE & & & \\
f -41 are of grade E and 32 of grade EE &
\end{tabular}

Table 7 Mechanical properties of glued laminated timber of visually graded maritime pine

\begin{tabular}{|c|c|c|c|}
\hline & \multirow{2}{*}{$\begin{array}{l}\text { Property } \\
\left(\mathrm{N} / \mathrm{mm}^{2}\right)\end{array}$} & \multicolumn{2}{|c|}{ Visual grade } \\
\hline & & $\mathrm{E}$ & EE \\
\hline \multirow{2}{*}{$\begin{array}{l}\breve{D}^{\prime} \\
\stackrel{\Xi}{\Xi}\end{array}$} & Tension, $\mathrm{f}_{\mathrm{t}, 0, \mathrm{l}, \mathrm{k}}{ }^{\mathrm{a}}$ & 10.8 & 21.0 \\
\hline & Average modulus of elasticity, $\mathrm{E}_{0,1 \text {,mean }}{ }^{\mathrm{a}}$ & 12000 & 14000 \\
\hline \multirow{3}{*}{ 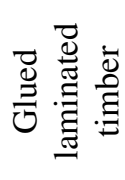 } & Bending, $f_{m, g, k}$ & 19.4 & 31.2 \\
\hline & Average modulus of elasticity, $\mathrm{E}_{0, \mathrm{~g}, \text { mean }}$ & 12600 & 14700 \\
\hline & Characteristic modulus of elasticity, $\mathrm{E}_{0, \mathrm{~g}, 05}$ & 10200 & 11900 \\
\hline${ }^{a}-\operatorname{Accc}$ & rding to NP ENV 1995-1-1 (1998) & & \\
\hline
\end{tabular}

Tabelle 1

Scherfestigkeit des Holzes und der Klebstofffugen - Aushärtung bei Raumtemperatur

Tabelle 2 Mittlere Delaminierung in Abhängigkeit der Behandlungsstufe und der

Aushärtungstemperatur

Tabelle 3

Biegefestigkeit der Keilzinkenverbindungen in N/mm²

Tabelle 4

Ergebnisse der Biegeprüfungen der Träger in N/mm²

Tabelle 5

Mechanische Eigenschaften in den äußeren vier Lamellen der verwendeten Bretter (kombiniertes

Brettschichtholz) und der Brettschichtholzträger

Tabelle 6

Mechanische Eigenschaften aller Bretter (homogenes Brettschichtholz) und der

Brettschichtholzträger

Tabelle 7

Mechanische Eigenschaften von Brettschichtholz aus visuell sortiertem Strandkiefernholz 


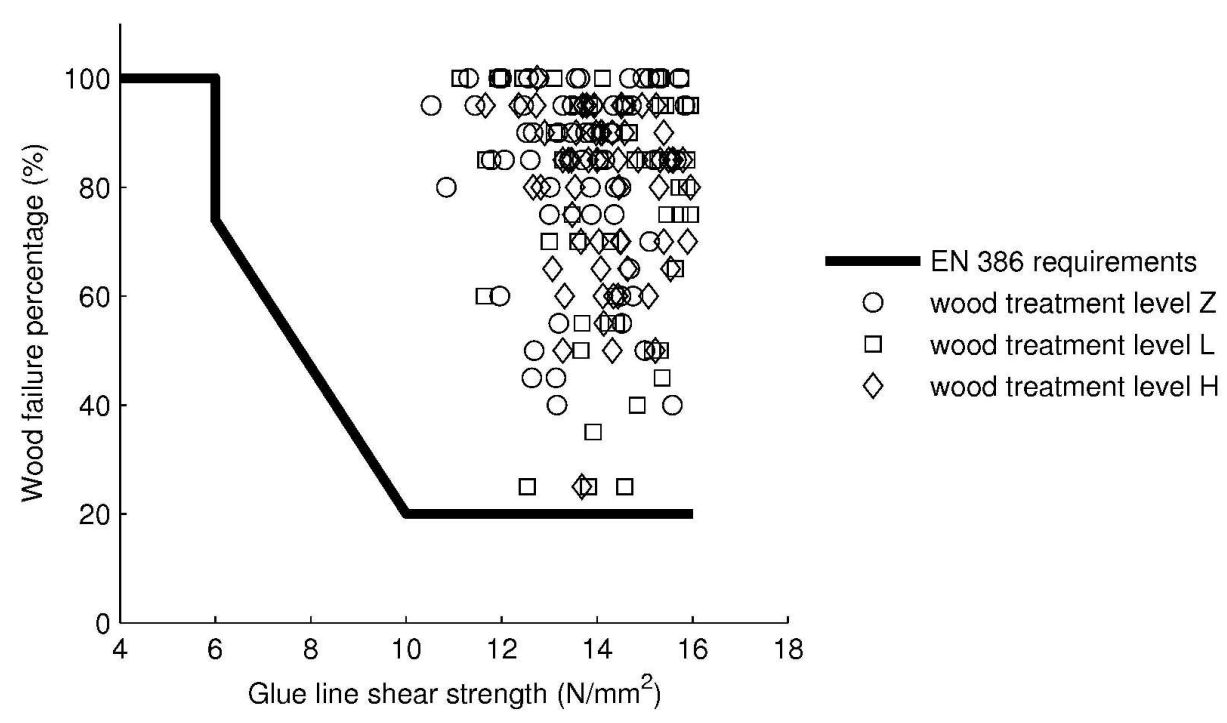

Fig. 1 Glue line shear test results (individual values) - cure at room temperature $146 \times 85 \mathrm{~mm}(600 \times 600 \mathrm{DPI})$ 
Fig. 2 Average shear strength of glue lines and wood - cure at higher temperatures $148 \times 66 \mathrm{~mm}(600 \times 600 \mathrm{DPI})$ 


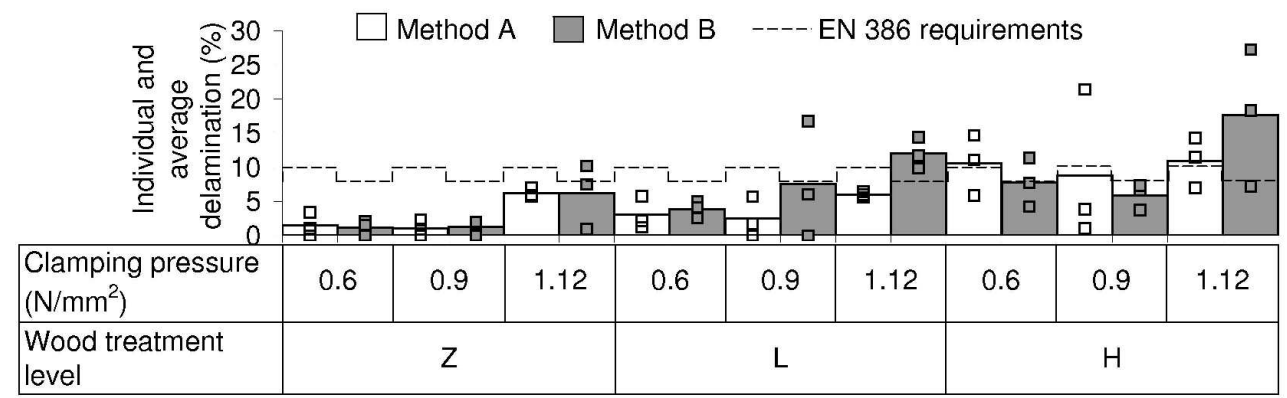

Fig. 3 Results of the delamination tests - cure at room temperature $143 \times 47 \mathrm{~mm}(600 \times 600 \mathrm{DPI})$ 


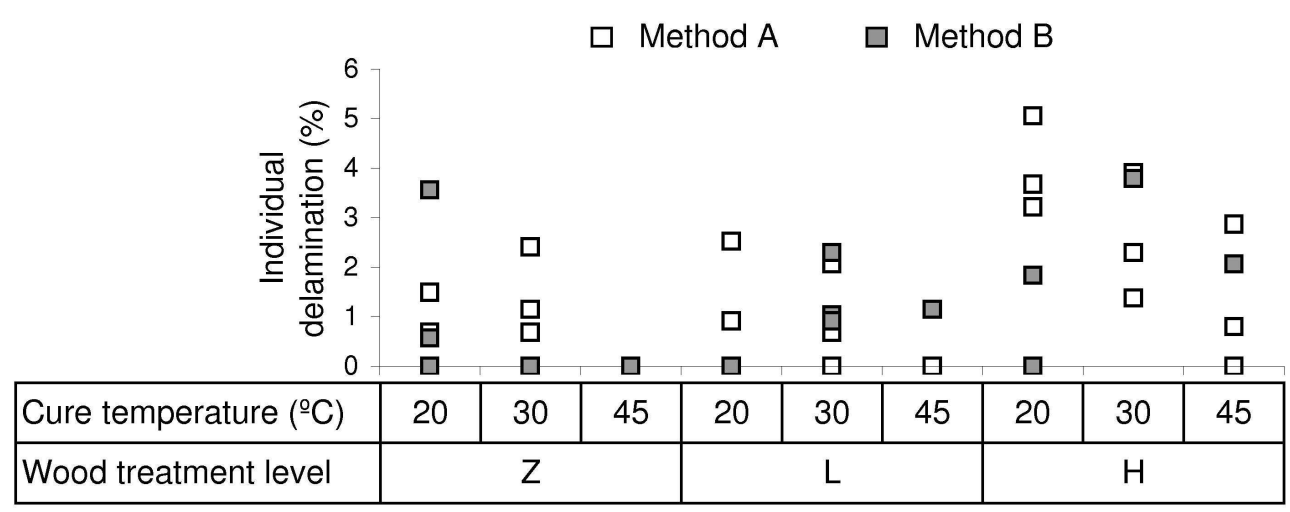

Fig. 4 Results of delamination tests - cure at higher temperatures $120 \times 49 \mathrm{~mm}(600 \times 600 \mathrm{DPI})$ 


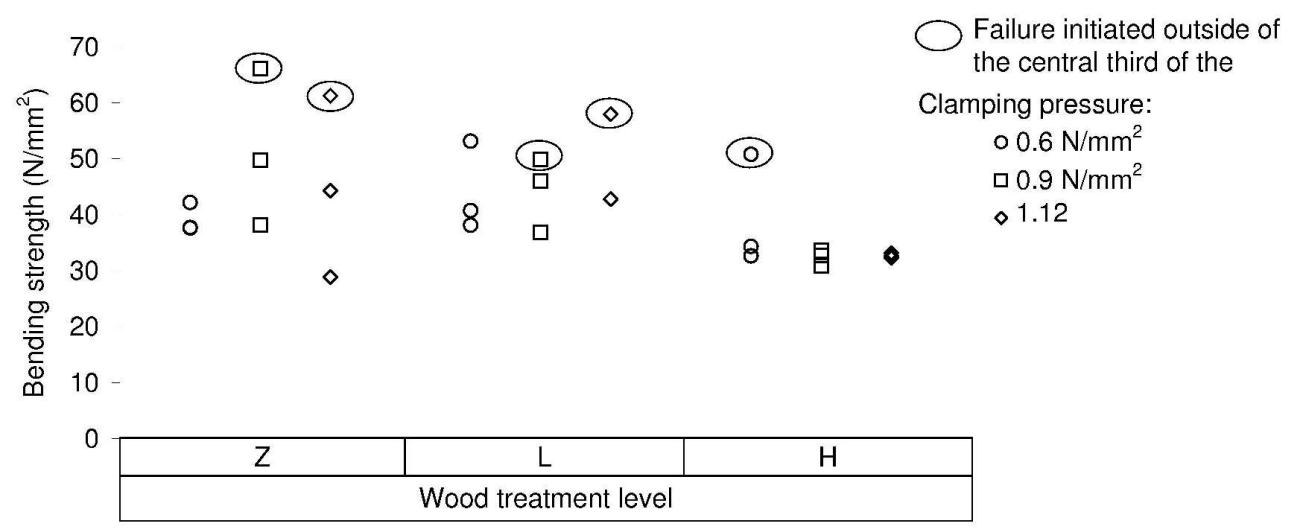

Fig. 5 Bending strength of beams. Values are corrected by ksize factor, according to EN 1194 (2002) $148 \times 62 \mathrm{~mm}(600 \times 600 \mathrm{DPI})$ 


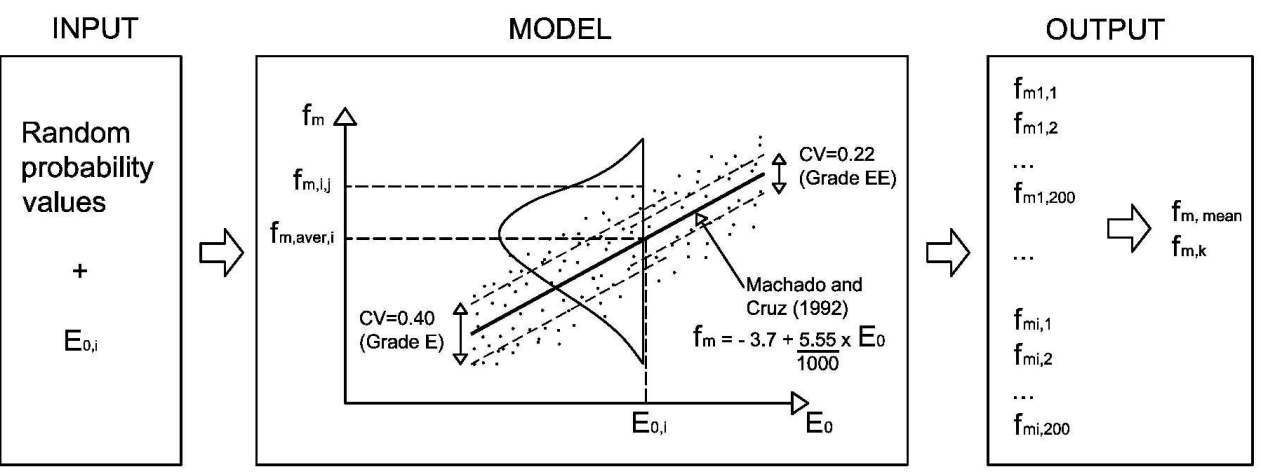

$E_{0,1}$ - minimum modulus of elasticity of plank $i$

$\mathrm{f}_{\mathrm{m}}$ - bending strength

$f_{m, \text { mean }}$ - mean bending strength

$f_{m, k}$ - characteristic bending strength

$\mathrm{CV}$ - coefficient of variation

$f_{m, i j}$ - bending strength for plank $i$ and for the $\mathrm{j}$ random probability value $f_{m, a v e r, i}$ - average bending strength of plank $i$

Fig. 6 Scheme of the Monte Carlo simulation used to estimate the strength of the lamellas $157 \times 90 \mathrm{~mm}(600 \times 600 \mathrm{DPI})$ 